\title{
Labour motivation of financial inspectors of agricultural enterprises
}

\author{
Iryna Perevozova \\ Entrepreneurship and Marketing \\ Department \\ Ivano-Frankivsk national technical \\ university of oil and gas \\ Ivano-Frankivsk, Ukraine \\ orcid.org/0000-0002-3878-802X
}

\author{
Oleh Dzoba \\ Institute of Economics and \\ Management \\ Ivano-Frankivsk national technical \\ university of oil and gas \\ Ivano-Frankivsk, Ukraine \\ orcid.org/0000-0003-0385-3693 \\ Nadiia Daliak* \\ Entrepreneurship and Marketing \\ Department \\ Ivano-Frankivsk National Technical \\ University of Oil and Gas \\ Ivano-Frankivsk, Ukraine \\ nadiya_d82@ukr.net
}

\author{
Zoriana Krykhovetska \\ Department of Finance \\ Vasyl Stefanyk Precarpathian National \\ University \\ Ivano-Frankivsk, Ukraine \\ krizor1@rambler.ru
}

\begin{abstract}
Development of the socially oriented market economy of Ukraine, effective realization of reforms in this area and improvement of people's living standards are not possible without forming a high level of labour motivation of financial inspectors, particularly of agricultural enterprises. However, the absence of qualitative changes after the partition of land and property of economic entities of agrarian sector of economy negatively affected both their profitability and motivation of agrarian labour. Taking into account the relevance of the above-mentioned problem and the fact, that it has not been deeply studied and solved, the main objective of the research is to characterize the labor motivation of financial inspectors of agricultural enterprises and to develop measures of promoting it. The methodological basis of this research comprises the scientific dialectical method of cognition, where the research object is studied as a dynamic system in the process of its development. The methods of comparison, analysis and synthesis, induction and deduction methods have been applied in studying and generalizing theoretical and practical developments. Furthermore, the research is based on legal and regulatory economic documents, developments of research institutions and scientists-economists as well as findings of monographic studies.
\end{abstract}

Our findings have it that the main components of the models of labor motivation of financial inspectors of agricultural enterprises are as follows: material (meeting the priority needs of workers); socio-psychological (focusing on satisfying peasants' top- level needs), complex (combination of the best material and socio-psychological incentives). The first component is the dominant one, as the workers, first of all, wish to improve their own well-being, whereas the second component does not make a substantial influence on the qualitative attitude to agrarians' labour. The obtained results of the research are a basis for studying and solving the problem of forming a high-level labor motivation of financial inspectors of economic entities of all areas of social activity as a whole.

Keywords-labour motivation; financial inspector; agricultural enterprise; agrarian sector of economy; material component of labor motivation model; socio-psychological component of labor motivation model; complex component of labor motivation model.

\section{INTRODUCTION}

The formation of a multi-vector market economy, the qualitative implementation of reforms in this field and the improvement of people's well-being are possible only on condition of increasing the labor motivation of financial inspectors, primarily, of agricultural enterprises. However, absence of positive effects of restructuring the agrarian sector of the economy (partition of land and property of collective agricultural enterprises) negatively affected the attitude to farmers' work, their living standards and the number of economic entities as a whole. So, in the period of 2010-2015, the number of employees in the agrarian sector of the economy of Ukraine decreased by almost 200 thousand people, and in comparison with industry the number became 4 times smaller. Besides, the number of agricultural enterprises for the above-mentioned period decreased by more than 4 thousand units [Agriculture of Ukraine 2015: 31, 49]. This situation destabilizes demand and supply at the labor market, reduces the amount of tax revenues to the budgets of all levels and deepens the degradation of rural areas as a whole.

Therefore, the development and implementation of effective measures aimed at improving the attitude to farmers' work is a vital issue at the present stage of Ukrainian economic development. The problems of labor motivation and financial controlling have been studied by Ukrainian and foreign scientists, economists, businessmen such as A. Bugutsky, G. Kupalova, V. Diesperov [Bugutsky, Kupalova, Diesperov 1993], I. Davidovich [Davidovich 2008], O. Tereshchenko, N. Babiak [Tereshchenko, Babiak 2013], L. Chervinska [Chervinska 19971, G. Ford [Ford 1980], R. Griffin [Griffin 1990], R. Kopelman [Kopelman 1982], A. Maslow [Maslow 1963], T. Mawhinney [Mawhinney 1984], W. Ouchi [Ouchi 1980] and others. They have defined the basic principles related to the development of labor motivation and financial controlling in certain areas of public activity. However, the problem of a comprehensive assessment of the motivation of 
labor activity of financial inspectors of agricultural enterprises in the context of the transformation of socioeconomic relations in the agrarian sector of economy has not been studied thoroughly enough.

Taking into consideration the importance of the abovementioned problem, and the fact, that it has not been solved yet, the main objective of the present research is the description of labor motivation of financial inspectors of agricultural enterprises and the development of measures of promoting it. In order to achieve this objective, we defined the following main tasks: - to create a conceptual apparatus of interpreting the concepts "the labor motivation of an employee" and "financial controller" at agricultural enterprises; - to define and characterize the main components of the models of labor motivation of financial inspectors of agricultural enterprises; - to suggest measures for effective implementation of the components of models mentioned above.

\section{FINDINGS OF THE RESEARCH}

As a result of the analysis, we have discovered that scientists interpret the socio-economic concepts "the labor motivation of an employee" and "financial controller" in different ways which are mostly similar and differ only in certain components. The former category is known by most scientists as the conscious target human activity aimed at achieving specific goals related to the influence of a variety of internal and external economic, social, organizational, production, labor, political, environmental and other factors. At the same time, the majority of scientists equate the latter category with a person working in the system of financial management of the development of an economic entity on forecasting and planning mechanisms and tools reaching its stable financial condition [Davidovich 2008: 10; Tereshchenko, Babiak 2013: 10]. Considering the interpretations of the above-mentioned socio-economic concepts, we think it advisable to define and describe the main components of the models of labor motivation of financial inspectors of agricultural enterprises. Thus, the main components are as follows:

- material (meeting the workers' priority needs);

- socio-psychological (focus on meeting top-level needs of peasants);

- complex (combination of the best material and sociopsychological incentives) (see figure 1).

Figure 1 shows that the efficiency of labor motivation of financial inspectors of agricultural enterprises depends both on the adopted incentive model and on the profitability of the respective economic entity, which distributes individual motivational models in the structure. For example, the material model is most common in average and highly profitable farms, whereas the socio-psychological model prevails in enterprises with average or low profitability, and the complex model, which involves a combination of the two models described above, is typical of economically powerful, socially secured and stably working farms.

The suggested comprehensive methodological approach to studying labor motivation of financial inspectors of agricultural enterprises will contribute to identifying the most significant of its elements and to developing effective ways of improving them. In addition, it is necessary to analyze the specificity of the application of each of the above-mentioned motivational models in terms of certain types of financial inspectors, which we determined by means of monographic observation, expert assessments, multi-factor comparison and other components.

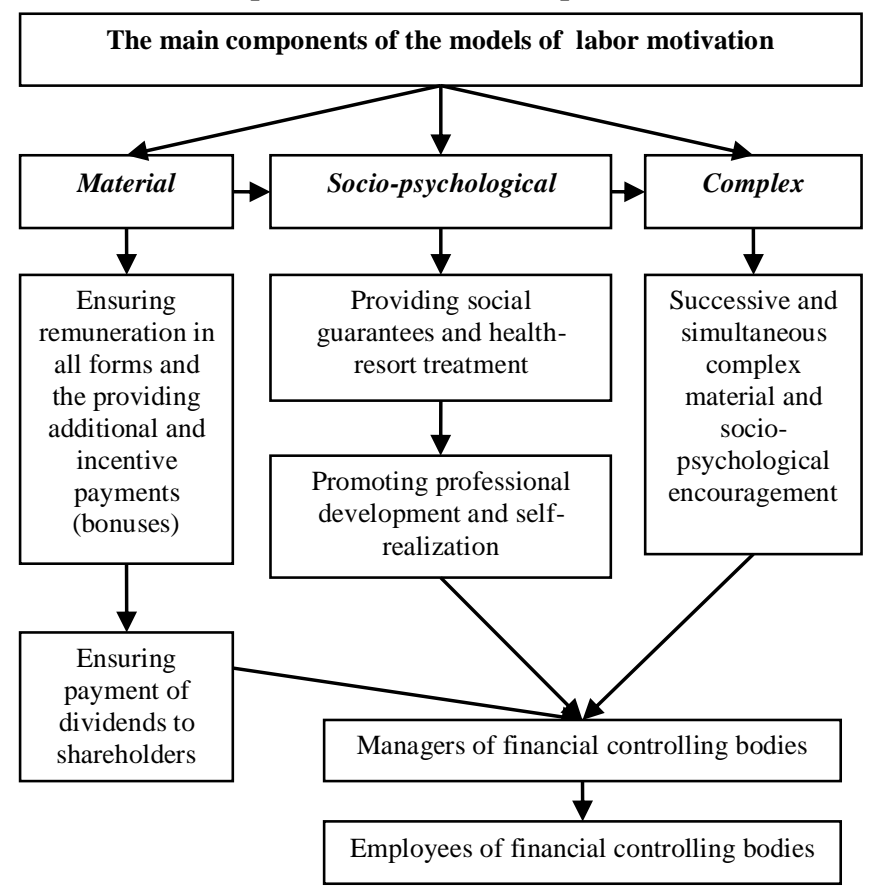

Fig. 1. The main components of the models of labor motivation of financial inspectors of agricultural enterprises

For this purpose, in 2017 we conducted a sociological survey of 465 employees of agricultural enterprises in Bila Tserkva, Volodar, Kagarlyk and Fastiv districts of Kyiv region. The questionnaire compiled by the author was aimed at studying their opinion related to the effectiveness of using the basic composite models of labor motivation of financial inspectors of agricultural enterprises. At the same time, the heads of financial controlling bodies and their deputies (60\%), employees of the relevant departments (40\%) took part in the poll, namely the categories of workers on whom both the possibility of creating controlling bodies (the heads of controlling bodies and their deputies) and their wellorganized and effective work (employees of the relevant bodies and other similar categories of workers) directly depend. In more detail, the results of this study are displayed in Table 1 .

The results in Table 1 show us that in total the existing wage level does not satisfy the needs of almost $31 \%$ of all financial inspectors of agricultural enterprises. That is, the amount of earnings does not satisfy the needs of more than every fourth employee. The current situation results from the fact that the wage level in the agricultural sector is lower than in the other sectors. Similar survey findings have been obtained with reference to the level of satisfaction of other material needs. However, imposibility to distribute profits and receive dividends by employees of financial controlling bodies negatively affects their attitude to work (on average more than $12 \%$ of respondents are dissatisfied with this condition). The current situation is caused by the legally fixed, almost sole right of the lessee - the entrepreneur, to 
pay only the minimum guaranteed rent for each land parcel meant for agricultural purposes, where the size of the latter, significantly depends on the results of financial and economic activity of this entrepreneur.

TABLE I. SHARE OF FINANCIAL INSPECTORS OF AGRICULTURAL ENTERPRISES OF KYIV REGION, THAT ARE DISSATISFIED WITH FINANCIAL INCENTIVES, IN 2017, \%

\begin{tabular}{|l|c|c|c|}
\hline \multicolumn{1}{|c|}{ Incentive } & $\begin{array}{c}\text { Managers } \\
\text { and their } \\
\text { deputies }\end{array}$ & $\begin{array}{c}\text { Employees of } \\
\text { financial } \\
\text { controlling } \\
\text { bodies }\end{array}$ & Total \\
\hline Salary & 30,3 & 31,4 & 30,9 \\
\hline $\begin{array}{l}\text { Additional } \\
\text { payments and } \\
\text { bonuses }\end{array}$ & 18,2 & 30,3 & 24,2 \\
\hline $\begin{array}{l}\text { Sick leaves and } \\
\text { other social } \\
\text { payments }\end{array}$ & 19,4 & 15,2 & 17,3 \\
\hline $\begin{array}{l}\text { Timely payment of } \\
\text { wages }\end{array}$ & 18,5 & 12,6 & 15,5 \\
\hline Dividends & 13,6 & 10,5 & 12,1 \\
\hline Total & 100,0 & 100,0 & 100,0 \\
\hline
\end{tabular}

Although the material incentive model in these business entities is effective, the labor motivation of financial inspectors is generally low. So, in spite of the fact that more than $95 \%$ of the examined agricultural enterprises of Kyiv region have been restructured, most farmers are not satisfied with the results of this process. In our opinion, the main goal of the restructuring of enterprises in the agrarian sector of economy was to improve their economic condition and the quality of the working life of working peasants. However, at the present stage of development of this industry, this goal has not been achieved.

The majority of the respondents-agrarians of Kyiv region pointed out that after the partition of land and farms' property, the organization of production and their labor motivation did not change for the better. This is also confirmed by the results of our monographs on the evaluation of peasants' attitude to labor after the partition of land and farms' property, and the definition of desirable, in their opinion, ways of using the units (see Table 2). Thus, no more than $27 \%$ of workers of agricultural enterprises in all the above-mentioned areas of Kyiv region have a positive attitude to work (more than $51 \%$ of respondents worsened their attitude to work). Besides, not more than $5 \%$ of the peasants employed in the farms of those areas of Kyiv region are interested in the careful and efficient use of production means.

Other questions of the survey were answered similarly, which indicates the absence of an effective motivational mechanism in the agricultural enterprises of Kyiv region. In our opinion, in the first place, historically formed peasants' mentality of collectivism is a significant barrier to socioeconomic transformations in the modern conditions of development of the agrarian sector of Ukrainian economy.

The majority of peasants (67\% of the respondents) still do not fully understand the purpose, basic principles and measures provided by the process of the partition of land and property of agricultural enterprises. This complicates the formation of social, labor, land, property and other relations.
TABLE II. THE ATTITUDE OF FARMERS TO WORK AFTER THE PARTITION OF LAND AND PROPERTY OF AGRICULTURAL ENTERPRISES IN KYIV REGION, IN 2017,\% OF THE TOTAL NUMBER OF ANSWERS

\begin{tabular}{|c|c|c|c|c|}
\hline Suggested options & 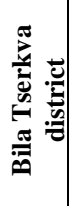 & 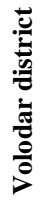 & 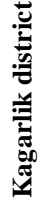 & 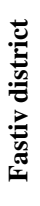 \\
\hline Attitude to work has not changed & 25 & 23 & 24 & 27 \\
\hline Attitude to work has got worse & 53 & 51 & 52 & 55 \\
\hline $\begin{array}{l}\text { Interest in the careful and efficient use of } \\
\text { production means has increased }\end{array}$ & 5 & 3 & 4 & 2 \\
\hline Reluctance to change the job & 10 & 13 & 8 & 9 \\
\hline $\begin{array}{l}\text { Discipline has improved and responsibility } \\
\text { has increased }\end{array}$ & 7 & 10 & 12 & 7 \\
\hline
\end{tabular}

It leads to the reduction of people's understanding of the direct connection between their earnings and the qualitative and quantitative result of their work, which negatively affects the peasants' attitude to work. In addition, the peasants expected to receive profits from the leased land shares and property. In this way, they strived to improve their own well-being and to really own the means of production, but they hoped in vain. For example, in Kyiv region, a lot of farmers are dissatisfied with the existing mechanism of using land shares (see Table 3).

TABLE III. THE DESIRED OPTIONS FOR USING LAND SHARES BY THE PEASANTS OF THE AGRICULTURAL ENTERPRISES OF KYIV REGION, IN $2017, \%$ OF THE TOTAL NUMBER OF RESPONSES

\begin{tabular}{|c|c|c|c|c|c|}
\hline \multirow{2}{*}{ Suggested options } & \multirow{2}{*}{ 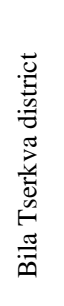 } & \multirow{2}{*}{ 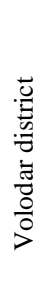 } & \multirow{2}{*}{ 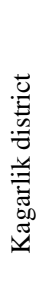 } & \multicolumn{2}{|c|}{$\begin{array}{c}\text { On } \\
\text { average } \\
\text { int } \\
\text { conditior } \\
\text { s }\end{array}$} \\
\hline & & & & 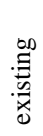 & 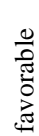 \\
\hline $\begin{array}{l}\text { To leave on the farm and receive } \\
\text { dividends }\end{array}$ & 20 & 18 & 19 & 19 & 52 \\
\hline $\begin{array}{l}\text { To lease out to a more efficient } \\
\text { manager }\end{array}$ & 25 & 22 & 24 & 24 & 9 \\
\hline $\begin{array}{l}\text { To leave the farm with units and } \\
\text { team up with other shareholders } \\
\text { for further management }\end{array}$ & 10 & 8 & 9 & 9 & 14 \\
\hline To become a farmer & 6 & 4 & 5 & 5 & 22 \\
\hline To sell the land & 36 & 46 & 42 & 41 & 2 \\
\hline Other options & 3 & 2 & 1 & 2 & 1 \\
\hline
\end{tabular}

Thus, the majority of shareholders of farms in the previously mentioned districts of Kyiv region desire to sell the land as soon as the appropriate mechanism for handling agricultural land is legally approved (more than $32 \%$ of the interviewed peasants). Primarily, it has to do with the lack of prospects for people to receive adequate material benefits (a significant amount of dividends) from any manager using the land share. Also, the low level of financial and logistical support of peasants minimizes their ability to cultivate their own land by themselves and make profit.

No more than $20 \%$ of respondents desire to leave the farmland and receive dividends. At the same time, more than $22 \%$ of the interviewed peasants in certain districts of Kyiv region tend to search for a more efficient manager of 
their shares. This involves different sizes of the peasants' land shares, the level of economic development of each enterprise, the mechanism of accrual and payment of dividends and other factors.

In addition, few landowners want to leave the farm and team up with the other shareholders for effective management (on average $9 \%$ of the interviewed peasants). Furthermore, the majority of peasants are reluctant to become farmers (on average $5 \%$ of the interviewed shareholders). In our opinion, the fact is due to the lack of effective and transparent mechanisms of regulating socioeconomic relations for the implementation of this type of activity.

Nevertheless, in favorable and stable conditions for the development of all spheres of social activity of the state, a considerable number of peasants would prefer farming (on average $22 \%$ of the interviewed shareholders). People also do not trust the current managers of enterprises that rent their shares, because they do not understand all the specific nature of the accrual and payment of dividends for the exploitation of their land. Although under favorable social and economic conditions for the development of the state, the majority of peasants would lease their own shares to any manager who would provide them with high rents and dividends (52\% of the interviewed shareholders).

Thus, in most agricultural enterprises of Kyiv region, the partition of their land and property resulted only in changing their organizational and legal form and the inefficient distribution of land and property among the peasants. In our opinion, the restructuring included a change in the socioeconomic principles of conducting economic activity by all agrarian enterprises, an increase in their economic power and improvement of every peasant's well-being. However, this goal was achieved only by some economic entities of the agrarian sector of Kyiv region's economy.

The way financial inspectors of agricultural enterprises treat their work is based on the use of a socio-psychological model of a motivational mechanism. It consists in meeting the needs of this category of employees in terms of pursuing a proper social status, career, ensuring professional development, self-actualization in work, and other components. For this purpose, they are created a favorable micro and macro environment for the implementation of the needs mentioned above.

However, despite all the described positive measures, the number of those dissatisfied with social and psychological incentives is quite high, which is confirmed by the results of monographic researches (see Table 4).

On average more than one out of every six workers is dissatisfied with their social status of a current performer, employee (18.1\% of respondents), with little chance for professional development and self-realization (in total more than $19 \%$ of respondents disapprove of each of the mentioned incentives, with reference to the discrepancy between the nature and content of labor, and their potential professional opportunities and the acquired experience, as well as the unsatisfactory conditions of agricultural work and leisure (on average more than $19 \%$ of respondents disapprove of the stimulus).
In addition, on average more than $18 \%$ of respondents complain about complicated labor relations caused by the violation of labor laws. It is known that due to the peculiarities of agricultural production, only a limited number of workers go on vacation in summer. Most of them have a rest in the autumn-winter, spring periods, or do not take vacation for several years in a row. As a result, the labor motivation of a third of the financial inspectors is negative because their social and psychological needs are insufficiently satisfied.

TABLE IV. THE RATIO OF FINANCIAL INSPECTORS OF AGRICULTURAL ENTERPRISES OF KYIV REGION, DISSATISFIED WITH FINANCIAL INCENTIVES, IN $2017, \%$

\begin{tabular}{|l|c|c|c|}
\hline \multicolumn{1}{|c|}{ Incentive } & $\begin{array}{c}\text { Managers } \\
\text { and their } \\
\text { deputies }\end{array}$ & $\begin{array}{c}\text { Employees of } \\
\text { Financial } \\
\text { Controlling Bodies }\end{array}$ & In total \\
\hline Social status & 17,4 & 18,7 & 18,1 \\
\hline $\begin{array}{l}\text { Professional } \\
\text { development }\end{array}$ & 18,3 & 20,7 & 19,5 \\
\hline Self-realization & 26,5 & 21,1 & 23,8 \\
\hline $\begin{array}{l}\text { Working and leisure } \\
\text { conditions }\end{array}$ & 19,6 & 20,3 & 20,0 \\
\hline $\begin{array}{l}\text { Labor relations in } \\
\text { general }\end{array}$ & 18,2 & 19,2 & 18,7 \\
\hline Total & 100,0 & 100,0 & 100,0 \\
\hline
\end{tabular}

Thus, the majority of financial inspectors of agricultural enterprises focus on external (a desire to meet material and social needs), rather than internal positive labor motivation (every employee's desire to realize their own psychological needs) [12]

Therefore, the heads of all the previously described economic entities try to meet, in the first place, material and social needs of the workers, and only then psychological ones. In our opinion, measures regarding the effective implementation of the two components of the above mentioned models are provided in the complex component of the model of the mechanism of agricultural enterprises financial inspectors' labor motivation. So, unlike others (material and socio-psychological), it is the best leverage on the use of personnel and creates preconditions for the formation of a positive attitude to work in the financial controlling bodies of agricultural enterprises.

Differentiation of attitude to labor in the conditions of the functioning of a complex component of labor motivation model results from the specific character of individual economic entities' activity and the organizing skills of their managers. At the same time, we have determined a unified approach to its formation and application at macro and micro levels (see Table 5).

The results in Table 5 show us that a rational combination of material and socio-psychological incentives is the foundation of this mechanism, where the first group of incentives is the basis, and the second one is the derivative. Moreover, the complex component of the model of the labor motivation mechanism for financial inspectors of agricultural enterprises provides for building up positive labor motivation of employees by means of establishing an optimal service infrastructure of the respective enterprises and a transparent mechanism for distributing shareholders' dividends. 
Therefore, the previously mentioned enterprises ensure effective functioning of the motivation mechanism.

TABLE V. MEASURES FOR EFFECTIVE IMPLEMENTATION OF A COMPLEX MODEL OF THE MECHANISM OF LABOR MOTIVATION OF AGRICULTURAL ENTERPRISES FINANCIAL INSPECTORS OF KYIV REGION, IN 2017

\begin{tabular}{|c|l|c|c|}
\hline \multirow{2}{|c|}{ Action } & $\begin{array}{c}\text { Macro } \\
\text {-level }\end{array}$ & $\begin{array}{c}\text { Micro- } \\
\text { level }\end{array}$ \\
\hline \multicolumn{3}{|c|}{ Material incentives } \\
\hline 1 & $\begin{array}{l}\text { Development, approval and implementation } \\
\text { of an effective pay mechanism }\end{array}$ & + & + \\
\hline 2 & $\begin{array}{l}\text { Ensuring timely and full payment in cash } \\
\text { and in kind }\end{array}$ & - & + \\
\hline 3 & $\begin{array}{l}\text { Creating conditions for providing additional } \\
\text { payments and bonuses for achieving and } \\
\text { exceeding the targets }\end{array}$ & - & + \\
\hline 4 & $\begin{array}{l}\text { Timely and full payment of dividends to } \\
\text { shareholders }\end{array}$ & - & + \\
\hline 5 & $\begin{array}{l}\text { Creating conditions for providing additional } \\
\text { state and / or non-state pensions }\end{array}$ & + & + \\
\hline \multicolumn{3}{|c|}{ Socio-psychological incentives } \\
\hline 1 & $\begin{array}{l}\text { Providing social benefits in accordance with } \\
\text { the law }\end{array}$ & + & + \\
\hline 2 & $\begin{array}{l}\text { Creating conditions for advanced training } \\
\text { and internships in leading domestic and } \\
\text { foreign public and private structures }\end{array}$ & - & + \\
\hline 3 & $\begin{array}{l}\text { Providing career development and social } \\
\text { recognition of performance }\end{array}$ & - & + \\
\hline 4 & $\begin{array}{l}\text { Providing the best young and experienced } \\
\text { professionals with additional social benefits }\end{array}$ & - & + \\
\hline 5 & $\begin{array}{l}\text { Creating and implementing a system of } \\
\text { gratification of leading performers for their } \\
\text { significant progress in work }\end{array}$ & - & + \\
\hline
\end{tabular}

\section{CONCLUSIONS}

Thus, having analyzed labor motivation of financial inspectors of agricultural enterprises, we identified three main components of models of their motivation mechanism - material, socio-psychological, and complex. Owing to certain material and socio-psychological incentives, the first two models contribute to developing only of some professionals' positive attitude to work. At the same time, we have found out that in order to increase the efficiency of labor motivation of farmers, it is advisable to use a complex motivational model. This involves a combination of the most effective material and socio-psychological incentives for the peasants. In our opinion, the previously mentioned approach will contribute to the development and implementation of effective methods of material and socio-psychological stimulation of financial inspectors, which will help improve the quality of farmers' working life and achieve positive results of financial and economic activity of agricultural enterprises in general.

\section{REFERENCES}

11 A.A. Bugutskiy, G.I. Kupalova, V.S. Diesperov et al., Motivatsiya truda i formirovanie ryinka rabochey sily [Motivation of labor and the formation of the labor market]. Kiev: Urozhay, 1993. [in Russian]

[2] I.E. Davidovich, Kontrolling [Controlling]. Kiev: Center of educational literature, 2008. [in Russian].

[3] Selskoe hozyaystvo Ukrainy 2015, Statisticheskiy sbornik. [Agriculture of Ukraine 2015: Statistical Yearbook]. Kiev: Gosudarstvennaya sluzhba statistiki Ukrainy, 2016. [in Russian].

[4] O.O. Tereschenko, and N.D. Babyak, Finansovyi kontrolling [Financial controlling]. Kiev: KNEU, 2013. [in Russian].

[5] L.P. Chervinskaya, Osnovyi motivatsii v menedzhmente [Fundamentals of motivation in management]. Sumy: GDP Mriya - 1, 1997. [in Russian].

[6] J. E. Ford,“A classification system for feedback procedures”. Journal of Organizational Behavior Management, no 2, 1980, pp. 183 - 191.

[7] R.W. Griffin, Management. Boston: Houghton Mifflin Company, 1990

[8] R.E. Kopelman, "Improving productivity through objective feedback", A review of the evidence. National Productivity Review, no 83,1982 , pp. 43-55.

[9] A. Maslow, "The need to know and the fear of knowing", Journal of General Psychology, no 68, 1963, pp. 111-124.

[10] T.C. Mawhinney, "Philosophical and ethnical aspects of organizational behaviour management: some evaluative feedback", Journal of Organizational Behaviour Management, no 6, 1984, pp. 5 -31 .

[11] W. Ouchi, "Markets, bureaucracies, and clans", Administrative Science Quarterly, no 25, 1980, pp. 129-141.

[12] I. Perevozova, N. Daliak and V. Babenko, Modeling of Financial "Support for the Competitiveness of Employees in the Mining Industry", Experimental Economics and Machine Learning for Prediction of Emergent Economy Dynamics. http://ceur-ws.org/Vol2422/paper36.pdf, 2019, pp. 444-454. 